\title{
MODEL PENGAMBILAN KEPUTUSAN PENERIMA BANTUAN RASKIN MENGUNAKAN METODE WEIGHTED PRODUCT (WP) DAN TOPSIS
}

\author{
Rustam $^{1}$, Dr.Rz.Abdul Aziz ${ }^{2}$ \\ Sistem Informasi ${ }^{1}$ Magister Teknik Informatika ${ }^{2}$ \\ STMIK Dian Cipta Cendikia Kotabumi ${ }^{1}$ IIB Darmajaya Bandar Lampung ${ }^{2}$ \\ Jl. Negara No.03 Candimas Kotabumi Lampung Utara \\ E-mail : rustamdcc89@gmail.com
}

\begin{abstract}
ABSTRAK
Penelitian ini bertujuan untuk mengetahui langkah-langkah ataupun model metode WP dan metode Topsis, serta membandingkan hasil analisis kedua metode tersebut, terkait pengambilan keputusan untuk menentukan penerima raskin di kecamatan way pengubuan lampung tengah.
\end{abstract}

Penyerapan tenaga kerja yang rendah serta kemampuan sumber daya manusia yang kurang memadai membuat kehidupan masyarakat dibawah garis kemiskinan. Usaha pemerintah dengan meluncurkan berbagai jenis bantuan tidak membuat tingkat kemiskinan berkurang. Beberapa faktor penyebabnya antara lain pemberian bantuan tidak tepat sasaran dan kriteria yang digunakan sebagai dasar penilaian belum maximal. Pemilihan metode harus sesuai untuk mengantisipasi kesalahan terhadap data yang akan digunakan. Metode Weighted Product (WP) dan Technique for Order Preference by Similarity to Ideal Solution (TOPSIS) bagian dari Multi-Attribut Decision Making (MADM) digunakan untuk melakukan perangkingan terhadap keseluruhan alternatif dari kriteria dan subkriteria yang telah ditentukan.

Implementasi kedua metoda terhadap kesepuluh alternatif (Kecamatan way pengubuan lampung tengah) ternyata memberikan hasil yang sangat baik mengunakan dua metode ini. Dan hasil perhitungan kedua metode ini berbeda maka disimpulkan hasil terkecillah yang terbaik adalah Topsis dengan nilai: 0,070137683

Kata kunci : SPK, Weighted Product (wp) dan Topsis

\section{ABSTRACT}

This study aims to determine the steps or models of the WP method and the Topsis method and compare the results of the analysis of the two methods, This study aims to determine the steps or models of the WP method and the Topsis method.

Low labor absorption and inadequate human resource capabilities make people's lives below the poverty line. Government efforts by launching various types of aid do not make poverty levels reduced. Some contributing factors include the provision of assistance that is not on target and the criteria used as a basis for assessments are not maximal. he selection of methods must be appropriate to anticipate errors in the data to be used. The Weighted Product (WP) method and Technique for Order Preference by Similarity to Ideal Solution (TOPSIS) part of Multi-Attribute Decision Making (MADM) are used to rank all alternatives of predetermined criteria and sub-criteria. The implementation of the two methods for the ten alternatives (Way of Pengubuan Central Lampung Subdistrict) turned out to give very good results. the calculation results of these two methods are different then it is concluded that the best results are Topsis with a value: 0.070137683

Keyword : SPK, Weighted Product (wp) dan Topsis

\section{PENDAHULUAN}

Perkembangan teknologi akhir- akhir ini berkembang semakin cepat dan pola berfikir manusia pun berkembang mengikuti
zaman.Hampir disemua lembaga atau instansi menggunakan teknologi komputer sebagai alat pengolahan data secara cepat, mudah, tepat dan efisien guna mempermudah pekerjaan yang 
sebelumnya dilakukan dengan manual. Dunia pemerintahan juga dapat di kategorikan dengan teknologi berbasis pengetahuan, faktadan penalaran dapat digunakan untuk menyelesaikan berbagai masalah disiplin ilmu diantarannya adalah masalah pengambilan keputusan dalam memilih warga yang tepat untuk menerima bantuan RASKIN. Program Beras Untuk Keluarga Miskin (RASKIN) merupakan subsidi pangan yang diperuntukkan bagi keluarga miskin sebagai upaya dari pemerintah untuk meningkatkan ketahanan pangan danmemberikanperlindungan pada keluarga miskin.

Di Kecamatan Way Pengubuan Kabupaten Lampung Tengah penyaluran yang terjadi pada bantuan penerimaan beras miskin masih belum optimal, penyaluran Raskin (Beras Miskin) pada masyarakat Kecamatan Way Pengubuan tersebut memiliki kecurangan dalam prosesnya. Akibatnya tidak seluruh warga miskin menerima bantuan Raskin (Beras Miskin) dan banyak warga yang tidak miskin menerimanya. Sehingga banyak warga protes karena warga yang seharusnya menerima bantuan tetapi tidak mendapat bantuan tersebut, begitupun sebaliknya. Dengan ini penulis mengangkat judul "Analisa Sistem Pendukung Keputusan Kelayakan Penerimaan Bantuan Raskin Dengan Metode Weighted Product (WP) dan Technique for Order Preference by Similarity to Ideal Solution (TOPSIS) (Studi Kasus: Kecamatan Way Pengubuan Lampung Tengah ).

Untuk itu dibutuhkan sebuah sistem pendukung keputusan.dengan adanya sistem pendukung keputusan (SPK) bertujuan untuk melakukan pengambilan keputusan dengan lebih cepat dan akurat.

Adanya kebijakan atau penemuan sistem dalam pengambilan keputusan sesuai dengan metode yang dirancang maka diharapkan proses penyeleksiannyapun menjadi lebih cepat selesai. Suatu keahlian dalam pengambilan keputusan yang cepat dan cermat akan menjadi kunci keberhasilan dalam persaingan global dan untuk mengambil sebuah keputusan tentu diperlukan analisis-analisis dan perhitungan yang matang, dan itupun harus disesuaikan dengan banyak atau sedikitnya kriteria yang mempengaruhi permasalahan yang membutuhkan suatu keputusan. salah satu metode yang digunakan adalah Weighted Product (WP) dan Technique for Order Preference by Similarity to Ideal Solution (TOPSIS) merupakan suatu metode penentuan urutan (prioritas) dalam analisis multikriteria dapat menggunakan cara perkalian untuk menghubungkan rating atribut, dimana rating tiap atribut harus dipangkatkanterlebih dahulu dengan bobot atribut yang bersangkutan.

\section{Sistem PendukungKeputusan}

Sebuah Sistem Pengambilan Keputusan dapat dikatakan pengembangan lebih lanjut dari sistem informasi manajemen terkomputerisasi yang dirancang sedemikian rupa sehigga bersifat interaktif dengan pemakainya Adapun Sifat interaktif ini dimaksudkan untuk memudahkan integrasi antara berbagai komponen dalam proses pengambilan keputusan seperti prosedur, kebijakan, teknik analisis, serta pengalaman dan wawasan manajerial guna membentuk suatu kerangka keputusan yang bersifat fleksibel [7]

\subsection{Ciri-ciri Decision Support System (DSS)} adapun ciri-ciri sebuah DSS seperti yang dirumuskan oleh Alters Keen adalah sebagai berikut:

DSS ditujukan untuk membantu pengambilan keputusan-keputusan yang kurang terstruktur dan umumnya dihadapi oleh para manajer yang berada di tingkat puncak.DSS merupakan gabungan antara kumpulan model kualitatif dan kumpulandata. [4]

1. DSS memiliki fasilitas interaktif yang dapat mempermudah hubungan antara manusia dengankomputer.

2. DSS bersifat luwes dan dapat menyesuaikan dengan perubahanperubahan yang terjadi.

\subsection{Karakteristik, Kemampuan dan}

\section{Keterbatasan SPK}

Adanya sebuah definisi yang dikemukakan mengenai pengertian dan penerapan dari sebuah DSS, sehingga menyebabkan terdapat banyak sekali pandangan mengenai sistem tersebut. Selanjutnya Turban (1996), menjelaskan terdapat sejumlah karakteristik dan kemampuan dari DSS yaitu:

1. Karakteristik DSS

1. Mendukung seluruh kegiatanorganisasi

2. Mendukung beberapa keputusan yang salingberinteraksi

3. Dapat digunakan berulang kali dan bersifatkonstan

4. Terdapat 2 komponen utama (data dan 
model)

5. Menggunakan baik data eksternal dan internal

6. Memiliki kemampuan what-if analysis dan goal seekinganalysis

7. Menggunakan beberapa model kuantitatif

2. Kemampuan DSS

1. Membantu pembuatan keputusan manajemen dalam menangani masalah semi terstruktur dan tidak terstruktur

2. Tingkat manajemen akan membantu manajer dari tingkat atas sampai dengan tingkat bawah

3. Melakukan pembuatan keputusan secara kelompok maupun perorangan

4. Membantu Pembuatan keputusan yang saling bergantung dan berurutan

5. Tahap-tahap pembuatan keputusan antara lain intelligensi, desain, choice, dan implementation

6. Membantu berbagai bentuk proses pembuatan keputusan dan jenis keputusan

7. Cara untuk melakukan adaptasi setiap saat dan bersifat fleksibel

8. Cara aatau kemudahan melakukan interaksi system

9. Menekankan efektivitas dalam pembuatan keputusan dari pada efisiensi

10. Sangat mudah dikembangkan oleh pemakaiakhi

11. Model pemodelan dan analisis pembuatan keputusan

12. Mudahan melakukan pengaksesan berbagai sumber dan format data

\subsection{TAHAPAN}

\section{PROSESPENGAMBILANKEPUTUSAN}

Menurut Simon ada 4 tahap yang harus dilalui dalam proses pengambilan keputusan (Desi Leha Kurniasih:2017) yaitu:

2.3.1 Penelusuran (intelligence)

Tahap ini merupakan tahap pendefinisian masalah serta identifikasi informasi yang dibutuhkan yang berkaitan dengan persoalan yang di hadapi serta keputusan yang akan diambil.

\subsubsection{Perancangan (design)}

Bagian ini merupakan tahap analisa dalam kaitan mencari atau merumuskan alternatif-alternatif pemecahan masalah.

2.3.3 Pemilihan (choise)

Yaitu memilih alternatif solusi yang diperkirakan paling sesuai.

\subsubsection{Implementasi (implementation) \\ Bagian ini merupakan tahap pelaksanaan dari keputusan yang telah diambil.}

\subsection{METODE WEIGHTED PRODUCT (WP)}

Metode Weighted Product adalah salah satu metode penyelesaian pada masalah Multi atributte decision making (MADM). Metode ini mengevaluasi beberapa alternatif terhadap sekumpulan atributatau kriteria, dimana setiap atribut saling tidak bergantung satu dengan yang lainnya. [9]

Menurut Yoon (Eni Suryeni : 2006) Metode Weighted Product menggunakan teknik perkalian untuk menghubungkan rating atribut, dimana rating tiap atribut harus dipangkatkan terlebih dahulu dengan bobot atribut yang bersangkutan. Proses ini sama halnya dengan proses normalisasi. Preferensi untuk alternative Ai diberikan sebagai berikut.

$s_{i}=\prod_{j=1}^{n} x_{i j}$

Dengan $\mathrm{i}=1,2 \ldots . \mathrm{m}$; dimana $\sum w_{j}=1 w_{j}$ adalah pangkat bernilai positif untuk keuntungan dan bernilai negatif untuk atribut biaya.

$w_{j} \frac{w_{j}}{\sum w_{j}}$

Pereferensi relatif dari setiap alternatif, diberikan sebagai:

$V_{i}$

$=\frac{\prod_{j=1}^{n} X_{i j} \quad w j}{\prod_{j}^{n}\left(x *_{i j}\right) \quad w j}$

Untuk keriteria nya terbagi dalam dua katergori yaitu bernilai positif termasik dalam kereteria keuntungan (benefit) dan yang bernilai negatif termasuk dalam kereteria biaya (cost).

\subsection{TECHNIQUE FOR ORDER PREFERENCE BY SIMILARITY TO IDEAL SOLUTION (TOPSIS)}

Topsis adalah salah satu metode yang bisa membantu peroses pengambilan keputusan yang optimal untuk menyelesaikan masalah keputusan secara peraktis. Hal ini disebabkan karna konsepnya sederhana dan mudah dipahami, komputasinya efisien dan memiliki kemampuan untuk mengatur kinerja relatif dari alternatif-alternatif keputusan dalam bentuk matematik sederhana [4]

Secara umum, prosedur TOPSIS mengikuti 
langkah-langkah sebagai berikut:

1. Menentukan matriks keputusan yang ternormalisasi

2. Menghitung matriks keputusan ternormalisasi yang terbobot

3. Menghitung Matrik solusi ideal positif dan matrik solusi ideal negatif

4. Menghitung jarak antara nilai setiap alternatif dan matrik solusi ideal positif dan matrik solusi ideal negatif

5. Menghitung nilai preferensi untuk setiaf alternatif

TOPSIS membutuhkan reting kinerja setiap alternatif $A_{i}$ pada setiap kereteria $y_{i}^{+}$yang ternormalisasi, yaitu:

$r i j=$

$\frac{x i j}{\sqrt{\sum_{i=1}^{m} X_{i j}^{2}}}$

Solusi ideal positif $A^{+}$dan solusi ideal negatif $A^{-}$dapat ditentukan berdasarkan reting bobot ternormalisasi $\left(Y_{i j}\right)$ sebagai:

$Y_{i j}=$

$W_{i} r_{i j}$

$A^{+}$

$A^{-}$

$=\left(y_{1}^{-}, y_{2}^{-}, \ldots \ldots \ldots \ldots y_{n}^{-}\right)$

Dengan

$y_{j}^{+}=$

$\int_{\text {max }} y_{i j} j$ jika $j$ atribut keuntungan

$\left\{\begin{array}{c}i \\ \min _{i} y_{i j} j_{j i k a} j \text { atribut biaya }\end{array}\right.$

$y_{j}^{-}=$

$\left\{\begin{array}{c}\text { max } y_{i j} \text { jika } j \text { atribut keuntungan } \\ \min y_{i j} \text { jika } j \text { atribut biaya } \\ i\end{array}\right.$

Jarak antara antar alternatif $A_{i}$ dengan solusi ideal positif dirumuskan sebagai:

$D_{i}^{+}$

$=\sqrt{\sum_{j=1}^{n}\left(y_{i}^{+}-y_{i j}\right) \ldots \ldots \ldots \ldots \ldots \ldots \ldots \ldots(10)}$

$D_{i}^{-}$

$=\sqrt{\sum_{j=1}^{n}\left(y_{i j}-y_{i}^{-}\right)}$

Nilai prefrensi untuk setiap alternatif (Vi)

dibertikan sebagai

$V_{i}=\frac{D_{i}^{-}}{D_{i}^{+}+D_{I}^{+}}$

$\mathrm{i}=1,2 \ldots \ldots \mathrm{m}$.

Variance $=\quad: s^{2}=\frac{\sum(x-\bar{x})^{2}}{(n-1)}$

Standar Deviation $\quad: S D=\mathrm{S}=\sqrt{S^{2}}$

\begin{tabular}{|c|c|c|}
\hline $\begin{array}{l}\text { Srandard } \\
\qquad S^{S^{2}}\end{array}$ & Error & $=$ \\
\hline
\end{tabular}

\subsection{UKURAN TINGKAT KEMISKINAN}

Kemiskinan adalah salah satu persoalan mendasar yang menjadi pusat perhatian pemerintah di negara manapun salah satu aspek penting untuk mendukung Strategi Penanggulangan Kemiskinan adalah tersedianya data kemiskinan yang akurat dan tepat sasaran. Pengukuran kemiskinan yang dapat dipercaya dapat menjadi instrumen tangguh bagi pengambil kebijakan dalam memfokuskan perhatian pada kondisi hidup orang miskin. Data kemiskinan yang baik dapat digunakan untuk mengevaluasi kebijakan pemerintah terhadap kemiskinan, membandingkan kemiskinan antar waktu dan daerah, serta menentukan target penduduk miskin dengan tujuan untuk memperbaiki kondisi mereka.

\subsection{BERAS MISKIN (RASKIN)}

Raskin (beras miskin) merupakan subsidi pangan sebagai upaya pemerintah untuk mening katkan ketahanan pangan dan memberikan perlindungan pada keluarga miskin melalui pendistri busian beras yang diharapkan mampu menjangkau keluarga miskin.Tujuan pelaksanaan raskin ini yaitu untuk membantu keluarga miskin agar memperoleh subsidi beras miskin sebagai bagian dari upaya program pemerintah untuk perlindungan sosial masyarakat. Melalui sebuah kajian ilmiah, penamaan RASKIN menjadi nama program diharapkan akan menjadi lebih tepat sasaran dan mencapai tujuan RASKIN. (TNP2K.2014) [4]

\section{METODOLOGI PENELITIAN}

Metodologi penelitian mempunyai peranan sangat penting sekali dalam penelitian, karena pada metodologi penelitian ini menggambarkan langkah-langkah secara sistematis yang dilakukan dalam memecahkan permasalahan yang diangkat. Deskripsi dilengkapi dengan penyajian diagram alur pelaksanaan penelitian untuk memudahkan dalam memahami tahapan penelitian. Untuk lebih jelasnya tentang metodologi penelitian ini dapat di lihat pada Gambar di bawah ini : 


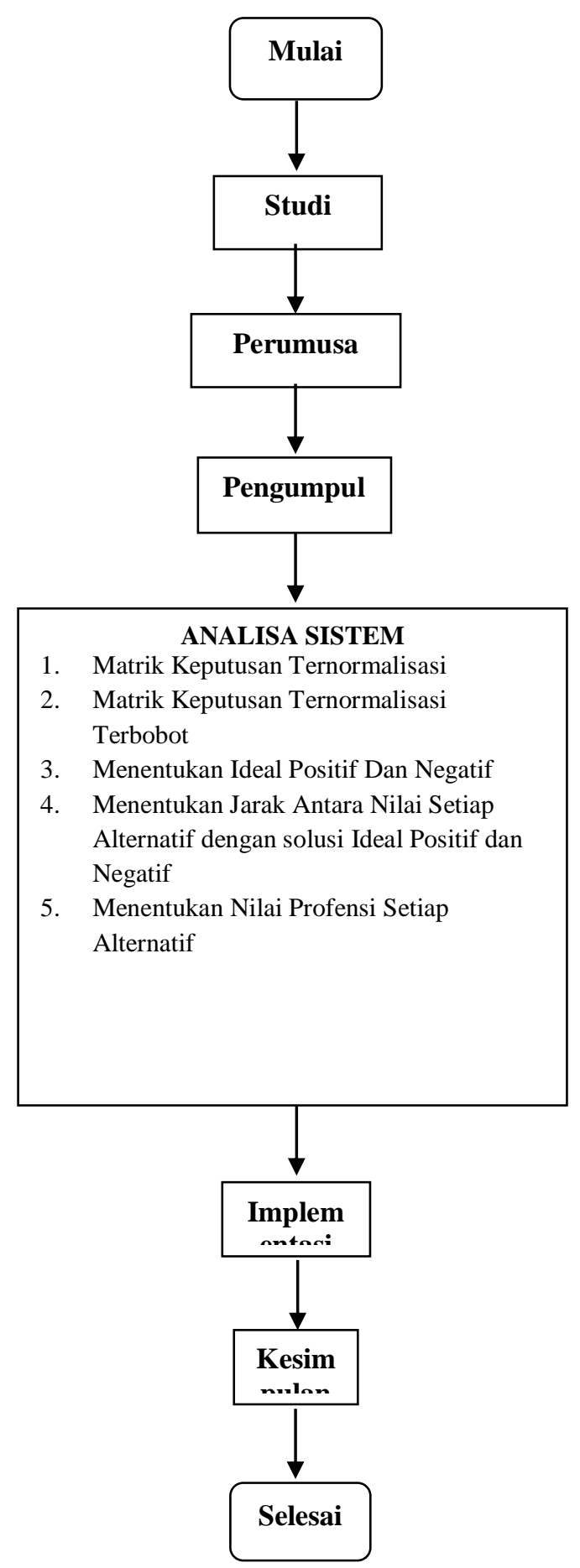

Gambar 1. Langkah-Langkah Peneliti

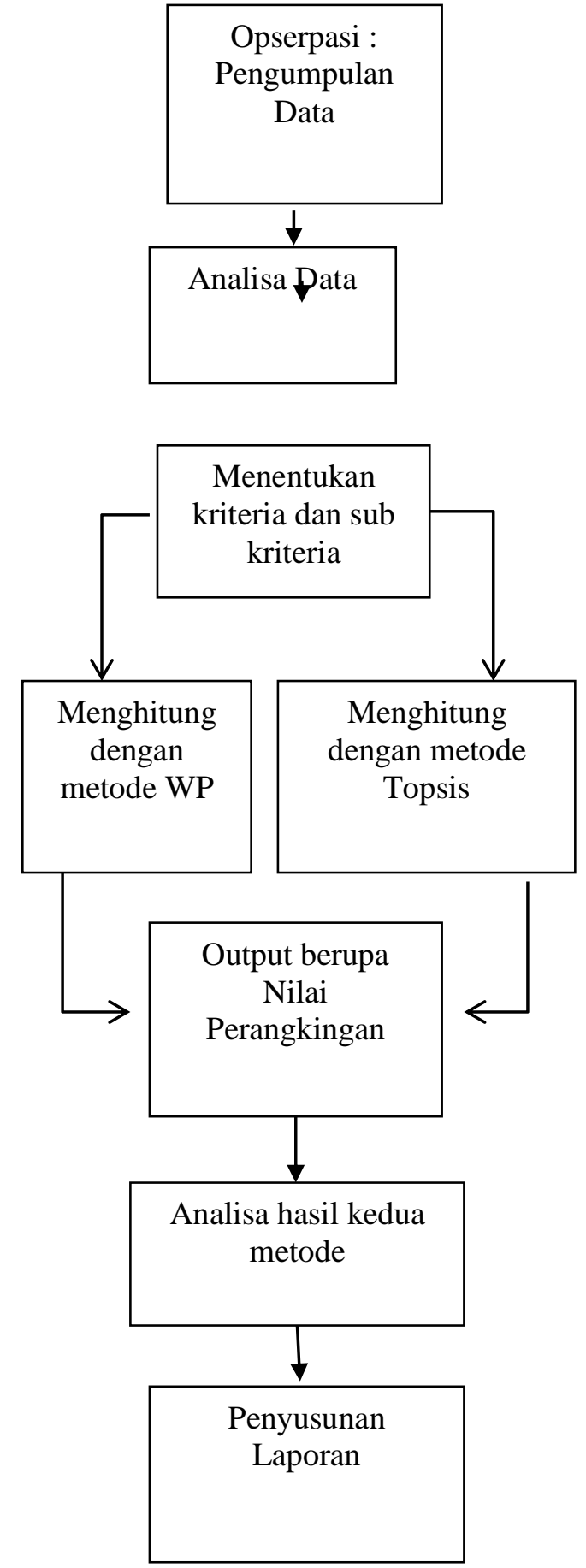

Gambar 2. Sistematika Penelitian

3.1 TEMPAT DAN WAKTU PENELITIAN Penelitian ini dilakukan di Kecamatan Way Pengubuan Lampung Tengah. Waktu penelitian dilakukan dari bulan November 2018 sampai dengan bulan Januari 2019 


\subsection{TEKNIK PENGUMPULAN DATA}

Pada tahap ini dilakukan dengan pengumpulan data-data yang ada di kecamatan way pengubuan tersebut. Semua tahap pada proses pengumpulan data-data tersebut diperoleh dari hasil studi pustaka. observasi lapangan dan wawancara.

\subsubsection{Studi Pustaka (Library Research)}

Studi pustaka dilakukan dengan tujuan untuk mengetahui metode apa yang akan digunakan untuk menyelesaikan permasalahan yang akan diteliti, serta mendapatkan dasar-dasar referensi yang kuat dalam menerapkan suatu metode yang akan digunakan dalam penelitian ini, yaitu dengan mempelajari jurnal-jurnal yang berhubungan dengan permasalahanyang akan dibahas.

\subsubsection{Observasi Lapangan}

Merupakan metode pengumpulan melalui pengamatan langsung. Proses memperoleh data dan informasi yang dibutuhkan, penulis secara langsung meminta data sekunder berupa data penduduk yang ada pada Kecamatan Way Pengubuan Lampung Tengah.

\subsection{PENGELOMPOKAN DATA}

Untuk penerapan metode WP dan TOPSIS ini tentunya diperlukan data-data inputan agar output sistem dapat berjalan sesuai dengan harapan, data-data yang dibutuhkan untuk implementasi sistem penulis kelompokkan kedalam data internal dan data eksternal.

\section{Data External}

Data external yaitu adalah data wargawarga yang akan diseleksi untuk menerima raskin. Data ini tentunya sumbernya berasal dari data sensus penduduk yang dilakukan oleh petugas desa secara rutin.

2. Data Internal

Data internal adalah data kriteria penerima raskin yang berasal dari Kecamatan Way Pengubuan Lampung Tengah. Data kriteria penerima raskin ini tentunya diambil berdasarkan Sumber data dari kecamatan Way Pengubuan Lampung Tengah.

\subsection{ANALISA DATA.}

Pada bagian ini berisi tentang penjelasan rumus /persamaan matematika menggunakan metode WP dan Topsis.

4. Menentukan Bobot scoring dalam kriteria > Sangat Rendah : 1 (memiliki peluang yang sangat rendah untuk mendapatkan raskin)

$>$ Rendah : 2 (memiliki peluang rendah untuk mendapatkan raskin)

$>$ Cukup : 3 (memiliki peluang yang cukup untuk mendapatkan raskin)

$>$ Baik : 4 (memiliki peluang yang baik untuk mendapatkan raskin)

$>$ Sangat Baik : 5 (memiliki peluang yang sangat baik untuk mendapatkan raskin)

Tabel 1. Pembobotan kriteria Penerima Raskin

\begin{tabular}{|c|c|c|c|c|}
\hline $\begin{array}{l}\mathrm{N} \\
\mathrm{o}\end{array}$ & Kriteria & Status & Skala & $\begin{array}{c}\text { Bobo } \\
t\end{array}$ \\
\hline \multirow{5}{*}{1} & \multirow{5}{*}{ Pekerjaan } & $\begin{array}{l}\text { PNS Gol } \geq \text { III } \\
\text { A }\end{array}$ & $\begin{array}{l}\text { Sangat } \\
\text { Renda } \\
\text { h } \\
\end{array}$ & 1 \\
\hline & & $\begin{array}{l}\text { Wiraswasta } \\
\text { Setara dengan } \\
\text { gol } \leq \text { II D }\end{array}$ & $\begin{array}{l}\text { Renda } \\
\mathrm{h}\end{array}$ & 2 \\
\hline & & $\begin{array}{l}\text { Karyawan } \\
\text { Swasta }\end{array}$ & Cukup & 3 \\
\hline & & Petani & Baik & 4 \\
\hline & & Buruh & $\begin{array}{l}\text { Sangat } \\
\text { Baik }\end{array}$ & 5 \\
\hline \multirow{5}{*}{2} & \multirow{5}{*}{$\begin{array}{l}\text { Tempat } \\
\text { tinggal }\end{array}$} & Milik Sendiri & $\begin{array}{l}\text { Sangat } \\
\text { Renda } \\
\mathrm{h}\end{array}$ & 1 \\
\hline & & Dinas & $\begin{array}{l}\text { Renda } \\
\mathrm{h}\end{array}$ & 2 \\
\hline & & Bebas Sewa & Cukup & 3 \\
\hline & & Kontrak/Sewa & Baik & 4 \\
\hline & & Numpang & $\begin{array}{l}\text { Sangat } \\
\text { Baik }\end{array}$ & 5 \\
\hline \multirow{5}{*}{3} & \multirow{5}{*}{$\begin{array}{l}\text { Sumber } \\
\text { Peneranga } \\
\mathrm{n}\end{array}$} & Listrik PLN & $\begin{array}{l}\text { Sangat } \\
\text { Renda } \\
\mathrm{h} \\
\end{array}$ & 1 \\
\hline & & Genset & $\begin{array}{l}\text { Renda } \\
\mathrm{h}\end{array}$ & 2 \\
\hline & & $\begin{array}{l}\text { Listrik Pakai } \\
\text { ACU }\end{array}$ & Cukup & 3 \\
\hline & & $\begin{array}{l}\text { Menyalur } \\
\text { listrik dari } \\
\text { Orang }\end{array}$ & Baik & 4 \\
\hline & & $\begin{array}{l}\text { Mengunakan } \\
\text { Lampu } \\
\text { minyak Tanah }\end{array}$ & $\begin{array}{l}\text { Sangat } \\
\text { Baik } \\
\end{array}$ & 5 \\
\hline \multirow{5}{*}{4} & \multirow{5}{*}{$\begin{array}{l}\text { Sumber } \\
\text { Air }\end{array}$} & Sumur Bor & $\begin{array}{l}\text { Sangat } \\
\text { Renda } \\
\mathrm{h} \\
\end{array}$ & 1 \\
\hline & & PDAM & $\begin{array}{l}\text { Renda } \\
\mathrm{h}\end{array}$ & 2 \\
\hline & & Sumur galian & Cukup & 3 \\
\hline & & Air Sungai & Baik & 4 \\
\hline & & $\begin{array}{l}\text { Numpang } \\
\text { Tetangga }\end{array}$ & $\begin{array}{l}\text { Sangat } \\
\text { Baik }\end{array}$ & 5 \\
\hline \multirow{3}{*}{5} & \multirow{3}{*}{$\begin{array}{l}\text { Bahan } \\
\text { Bakar } \\
\text { Memasak }\end{array}$} & $\begin{array}{l}\text { Kompor } \\
\text { Listrik }\end{array}$ & $\begin{array}{l}\text { Sangat } \\
\text { Renda } \\
\mathrm{h}\end{array}$ & 1 \\
\hline & & Kompor Gas & $\begin{array}{l}\text { Renda } \\
\mathrm{h}\end{array}$ & 2 \\
\hline & & Minyak Tanah & Cukup & 3 \\
\hline
\end{tabular}




\begin{tabular}{|c|c|c|c|c|}
\hline & & Arang & Baik & 4 \\
\hline & & Kayu Bakar & $\begin{array}{l}\text { Sangat } \\
\text { Baik }\end{array}$ & 5 \\
\hline \multirow{5}{*}{6} & \multirow{5}{*}{$\begin{array}{l}\text { Pembelian } \\
\text { Pakaian / } \\
\text { Tahun }\end{array}$} & $\begin{array}{l}\geq 4 \text { kali } \\
\text { setahun }\end{array}$ & $\begin{array}{l}\text { Sangat } \\
\text { Renda } \\
\mathrm{h}\end{array}$ & 1 \\
\hline & & 3 kali setahun & $\begin{array}{l}\text { Renda } \\
\mathrm{h} \\
\end{array}$ & 2 \\
\hline & & 2 kali setahun & Cukup & 3 \\
\hline & & 1 kali setahun & Baik & 4 \\
\hline & & $\begin{array}{l}\text { tidak pernah } \\
\text { sama sekali }\end{array}$ & $\begin{array}{l}\text { Sangat } \\
\text { Baik }\end{array}$ & 5 \\
\hline \multirow{5}{*}{7} & \multirow{5}{*}{$\begin{array}{l}\text { Konsumsi } \\
\text { Daging / } \\
\text { Tahun }\end{array}$} & $\begin{array}{l}\geq 4 \text { kali } \\
\text { setahun }\end{array}$ & $\begin{array}{l}\text { Sangat } \\
\text { Renda } \\
\mathrm{h}\end{array}$ & 1 \\
\hline & & 3 kali setahun & $\begin{array}{l}\text { Renda } \\
\mathrm{h}\end{array}$ & 2 \\
\hline & & 2 kali setahun & Cukup & 3 \\
\hline & & 1 kali setahun & Baik & 4 \\
\hline & & $\begin{array}{l}\text { tidak pernah } \\
\text { sama sekali }\end{array}$ & $\begin{array}{l}\text { Sangat } \\
\text { Baik } \\
\end{array}$ & 5 \\
\hline \multirow{5}{*}{8} & \multirow{5}{*}{$\begin{array}{l}\text { Pendidikan } \\
\text { Kepala } \\
\text { Keluarga }\end{array}$} & Sarjana & $\begin{array}{l}\text { Sangat } \\
\text { Renda } \\
\mathrm{h} \\
\end{array}$ & 1 \\
\hline & & SMU & $\begin{array}{l}\text { Renda } \\
\mathrm{h}\end{array}$ & 2 \\
\hline & & SMP & Cukup & 3 \\
\hline & & SD & Baik & 4 \\
\hline & & Tidak Sekolah & $\begin{array}{l}\text { Sangat } \\
\text { Baik }\end{array}$ & 5 \\
\hline \multirow{5}{*}{9} & \multirow{5}{*}{$\begin{array}{l}\text { Penghasila } \\
\text { n kepala } \\
\text { keluarga / } \\
\text { Bulan }\end{array}$} & $\begin{array}{l}\text { Rp.> } \\
5.000 .000\end{array}$ & $\begin{array}{l}\text { Sangat } \\
\text { Renda } \\
\mathrm{h} \\
\end{array}$ & 1 \\
\hline & & $\begin{array}{l}4.000 .000<X \\
\leq 3.500 .000\end{array}$ & $\begin{array}{l}\text { Renda } \\
\mathrm{h} \\
\end{array}$ & 2 \\
\hline & & $\begin{array}{l}2.500 .000<\mathrm{X} \\
\leq 2.000 .000\end{array}$ & Cukup & 3 \\
\hline & & $\begin{array}{l}1.500 .000<\mathrm{X} \\
\leq 1.000 .000\end{array}$ & Baik & 4 \\
\hline & & Rp. $\leq 800.000$ & $\begin{array}{l}\text { Sangat } \\
\text { Baik }\end{array}$ & 5 \\
\hline \multirow{5}{*}{10} & \multirow{5}{*}{ Tabungan } & $\begin{array}{l}\text { Rp. > } \\
4.000 .000\end{array}$ & $\begin{array}{l}\text { Sangat } \\
\text { Renda } \\
\mathrm{h} \\
\end{array}$ & 1 \\
\hline & & $\begin{array}{l}3.500 .000<\mathrm{X} \\
\leq 3.000 .000\end{array}$ & $\begin{array}{l}\text { Renda } \\
\mathrm{h}\end{array}$ & 2 \\
\hline & & $\begin{array}{l}2.500 .000<\mathrm{X} \\
\leq 2.000 .000\end{array}$ & Cukup & 3 \\
\hline & & $\begin{array}{l}1.500 .000<\mathrm{X} \\
\leq 1.000 .000\end{array}$ & Baik & 4 \\
\hline & & Rp. $\leq 500.000$ & $\begin{array}{l}\text { Sangat } \\
\text { Baik }\end{array}$ & 5 \\
\hline \multirow{5}{*}{11} & \multirow{5}{*}{$\begin{array}{l}\text { Lantai } \\
\text { Bangunan }\end{array}$} & $\begin{array}{l}\text { Marmar/Gran } \\
\text { et }\end{array}$ & $\begin{array}{l}\text { Sangat } \\
\text { Renda } \\
\mathrm{h} \\
\end{array}$ & 1 \\
\hline & & Keramik & $\begin{array}{l}\text { Renda } \\
\mathrm{h}\end{array}$ & 2 \\
\hline & & Semen Kasar & Cukup & 3 \\
\hline & & Kayu & Baik & 4 \\
\hline & & Tanah & $\begin{array}{l}\text { Sangat } \\
\text { Baik }\end{array}$ & 5 \\
\hline \multirow[t]{2}{*}{12} & \multirow{2}{*}{$\begin{array}{l}\text { Luas } \\
\text { Lantai }\end{array}$} & $7 * 3 \mathrm{~m} 2$ & $\begin{array}{l}\text { Sangat } \\
\text { Renda } \\
\mathrm{h} \\
\end{array}$ & 1 \\
\hline & & $6 * 6 \mathrm{~m} 2$ & $\begin{array}{l}\text { Renda } \\
\mathrm{h}\end{array}$ & 2 \\
\hline
\end{tabular}

\begin{tabular}{|l|l|l|l|l|}
\hline \multirow{4}{*}{} & & $4 * 7 \mathrm{~m} 2$ & Cukup & 3 \\
\hline & $3 * 6 \mathrm{~m} 2$ & Baik & 4 \\
\hline & & $\begin{array}{l}\text { Sangat } \\
\text { Baik }\end{array}$ & 5 \\
\hline
\end{tabular}

\subsection{MENGUMPULKAN DATA MATRIK ALTERNATIF}

Dalam melakukan pengumpulan data untuk mengisi matrik alternatif penulis menggunakan media form survey kepala keluarga yang diisi oleh petugas survey (form survey ada dilampiran). Sehingga didapatkan data matrik alternatif sebagai berikut :

Tabel 2. menunjukan data matrik alternatif

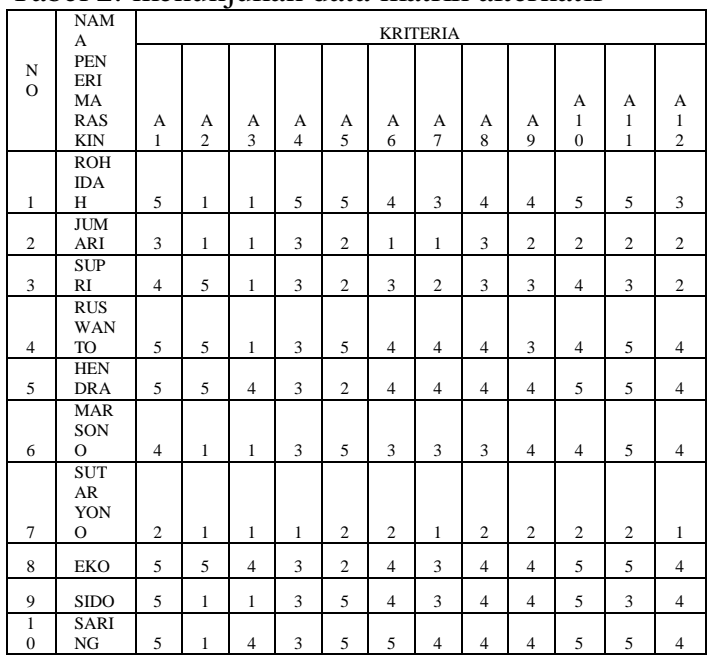

Catatan : penulis hanya menggunakan 10 data sebagai sample

Tabel 3. Standar Bobot Preferensi

\begin{tabular}{|l|c|}
\hline \multicolumn{2}{|c|}{ Bobot Preferensi } \\
\hline Kriteria & Bobot \\
\hline Pekerjaan & 2 \\
\hline Tempat tinggal & 2 \\
\hline Sumber Penerangan & 3 \\
\hline Sumber Air & 3 \\
\hline Bahan Bakar Memasak & 3 \\
\hline Pembelian Pakaian dalam setahun & 5 \\
\hline Konsumsi Daging & 3 \\
\hline Pendidikan Kepala Keluarga & 4 \\
\hline Penghasilan kepala keluarga & 2 \\
\hline Tabungan & 4 \\
\hline Lantai Bangunan & 4 \\
\hline Luas Lantai & 4 \\
\hline
\end{tabular}

\subsection{PROSES ANALISA MENGGUNAKAN} METODE WEIGHT PRODUCT

Proses analisa data menggunakan metode weight product dalam menyelesaikan masalah langkah-langkahnya sebagai berikut :

a. Melakukan perbaikan bobot preferensi. Bobot awal preferensi $\mathrm{W}=(2,2,3,3,3,5,5,4,2,4,4,4)$ seluruh bobot 
akan dimasukkan ke dalam persamaan Rumus

$$
\begin{aligned}
& W_{j}=\frac{w_{j}}{\sum w_{j}} \\
& W_{1}=\frac{2}{2+2+\cdots+4} \\
& =0,05128 \\
& W_{2}=\frac{2}{2+2+\cdots+4} \\
& =0,05128
\end{aligned}
$$

lakukan perhitungan untuk perbaikan bobot sampai dengan $W_{12}$

\begin{tabular}{|c|c|c|c|c|}
\hline \multirow[t]{2}{*}{$\mathrm{N}$} & \multicolumn{3}{|c|}{ Bobot Preferensi } & \multirow[b]{2}{*}{$\begin{array}{c}\text { Cost / } \\
\text { benefi } \\
t\end{array}$} \\
\hline & Kriteria & $\begin{array}{c}\text { skala } \\
\text { kepentinga } \\
n\end{array}$ & $\begin{array}{c}\text { Perbaika } \\
\text { n Bobot } \\
(W)\end{array}$ & \\
\hline 1 & Pekerjaan & 2 & 0,05128 & benefit \\
\hline 2 & $\begin{array}{l}\text { Tempat } \\
\text { tinggal }\end{array}$ & 2 & 0,05128 & benefit \\
\hline 3 & $\begin{array}{l}\text { Sumber } \\
\text { Penerangan }\end{array}$ & 3 & 0,07692 & benefit \\
\hline 4 & Sumber Air & 3 & 0,07692 & benefit \\
\hline 5 & $\begin{array}{l}\text { Bahan } \\
\text { Bakar } \\
\text { Memasak }\end{array}$ & 3 & 0,07692 & benefit \\
\hline 6 & $\begin{array}{l}\text { Pembelian } \\
\text { Pakaian } \\
\text { dalam } \\
\text { setahun }\end{array}$ & 5 & 0,12821 & benefit \\
\hline 7 & $\begin{array}{l}\text { Konsumsi } \\
\text { Daging }\end{array}$ & 3 & 0,07692 & benefit \\
\hline 8 & $\begin{array}{l}\text { Pendidikan } \\
\text { Kepala } \\
\text { Keluarga }\end{array}$ & 4 & 0,10256 & benefit \\
\hline 9 & $\begin{array}{l}\text { Penghasila } \\
\text { n kepala } \\
\text { keluarga }\end{array}$ & 2 & 0,05128 & benefit \\
\hline 10 & Tabungan & 4 & 0,10256 & benefit \\
\hline 11 & $\begin{array}{l}\text { Lantai } \\
\text { Bangunan }\end{array}$ & 4 & 0,10256 & benefit \\
\hline 12 & $\begin{array}{l}\text { Luas } \\
\text { Lantai }\end{array}$ & 4 & 0,10256 & benefit \\
\hline
\end{tabular}

$$
\begin{gathered}
W_{12}=\frac{4}{2+2+\cdots+4} \\
=0,10256
\end{gathered}
$$

Sehingga didapatkan bobot preferensi seperti dalam tabel 4.

Tabel 4. Perbaikan Bobot Preferensi

b. Menentukan nilai vector $\mathrm{s}$ yang dapat dihitung menggunakan rumus persamaan sebagai berikut :

$$
\begin{aligned}
& S_{i}=\prod_{j=1}^{n} X_{i j}^{W j} \\
& S_{1} \\
& =\left(5^{0,05128}\right) *\left(1^{0,05128}\right) \\
& *\left(1^{0,07692}\right) * \ldots *\left(3^{0,10256}\right) \\
& =3.485025 \\
& S_{2} \\
& =\left(3^{0,05128}\right) *\left(1^{0,05128}\right) \\
& *\left(1^{0,07692}\right) * \ldots *\left(2^{0,10256}\right) \\
& =1.743103 \\
& =\left(4^{0,05128}\right) *\left(5^{0,05128}\right) \\
& *\left(1^{0,07692}\right) * \ldots *\left(2^{0,10256}\right) \\
& =2.666037
\end{aligned}
$$

Lakukan perhitungan sampai dengan sejumlah data alternativf yang tersedia $S_{10}$

$S_{10}$ $=\left(5^{0,05128}\right) *\left(1^{0,05128}\right)$

$*\left(4^{0,07692}\right) * \ldots *\left(4^{0,10256}\right)$

$$
=4.039263
$$

Sehingga didapatkan hasil skor alternatif eperti pada tabel 5

Tabel 5. Nilai Vector $S$

\begin{tabular}{|c|c|c|}
\hline NO & NAMA ALTERNATIF & NILAI S \\
\hline 1 & S1 & 3.485025 \\
\hline 2 & S2 & 1.743103 \\
\hline 3 & S3 & 2.666037 \\
\hline 4 & S4 & 3.690315 \\
\hline 5 & S5 & 3.972937 \\
\hline 6 & S6 & 3.120424 \\
\hline 7 & S7 & 1.531966 \\
\hline 8 & S $~$ & 3.885984 \\
\hline 9 & S9 & 3.274923 \\
\hline 10 & S10 & 4.039263 \\
\hline
\end{tabular}

c. Menentukan Nilai vector yang akan digunakan Menghitung Preferensi (Vi) untuk perengkingan dengan memasukkan nilai $\mathrm{s}$ kedalam persamaan rumus : 


$$
\mathrm{V}_{\mathrm{i}}=\frac{\prod_{J=1}^{n} x_{i j} \mathrm{wj}}{\prod_{J=1}^{n}\left(x_{j} *\right) \mathrm{wj}}
$$

Sederhananya menjadi :

$$
\begin{aligned}
& V_{1}=\frac{S_{1}}{S_{1}+S_{2}+S_{3}+\cdots+S_{10}} \\
& = \\
& 3.485025 \\
& \overline{3.485024741+1.743103232+2.666037279+\ldots+4.039263138} \\
& =0.110953 \\
& V_{2}=\frac{S_{2}}{S_{1}+S_{2}+S_{3}+\cdots+S_{10}} \\
& = \\
& \begin{array}{l}
\frac{1.743103}{3.485024741+1.743103232+2.666037279+\ldots+4.039263138} \\
=0.055495
\end{array}
\end{aligned}
$$

\begin{tabular}{|c|c|c|c|}
\hline No & $\begin{array}{l}\text { NAMA } \\
\text { PENERIMA } \\
\text { RASKIN }\end{array}$ & V (Alias) & Nilai V \\
\hline 1 & ROHIDAH & V1 & 0.110953 \\
\hline 2 & JUMARI & V2 & 0.055495 \\
\hline 3 & SUPRI & V3 & 0.084879 \\
\hline 4 & RUSWANTO & V4 & 0.117489 \\
\hline 5 & HENDRA & V5 & 0.126486 \\
\hline 6 & MARSONO & V6 & 0.099345 \\
\hline 7 & SUTAR YONO & V7 & 0.048773 \\
\hline 8 & EKO & V8 & 0.123718 \\
\hline 9 & SIDO & V9 & 0.104264 \\
\hline 10 & SARING & V10 & 0.128598 \\
\hline
\end{tabular}

Lakukan perhitungan sampai mendapatkan $V_{10}$

$V_{10}=\frac{S_{10}}{S_{1}+S_{2}+S_{3}+\cdots+S_{10}}$

$=$ 4.039263

$3.485024741+1.743103232+2.666037279+\ldots+4.039263138$

\begin{tabular}{|c|c|c|c|}
\hline NO & \multicolumn{3}{|c|}{ Hasil Ranking (sort) } \\
\hline 1 & SARING & V10 & 0,128598 \\
\hline 2 & HENDRA & V5 & 0,126486 \\
\hline 3 & EKO & V8 & 0,123718 \\
\hline 4 & RUSWANTO & V4 & 0,117489 \\
\hline 5 & ROHIDAH & V1 & 0,110953 \\
\hline 6 & SIDO & V9 & 0,104264 \\
\hline 7 & MARSONO & V6 & 0,099345 \\
\hline 8 & SUPRI & V3 & 0,084879 \\
\hline 9 & JUMARI & V2 & 0,055495 \\
\hline 10 & SUTAR YONO & V7 & 0,048773 \\
\hline
\end{tabular}
$=0.128598$

Tabel. 6 Perhitungan Vektor

d. Setelah menghitung nilai vector $\mathrm{V}$ maka data vector tersebut harus diurutkan dari nilai terbesar hingga nilai terkecil. Maka akan muncul nilai seperti pada table. 7

Tabel. 7 Hasil Perengkingan

e. Berdasarkan tabel. 7 perhitungan dengan mengunakan metode Weighted Product (WP) menyatakan bahwa alternanif yang berhak menerima raskin adalah.

1. Saring

2. Hendra

3. Ruswanto

4. Rohodah

5. Sido

\begin{tabular}{|l|c|c|}
\hline \multicolumn{3}{|l|}{ Tabel 8. Pencarian Nilai Mean } \\
\hline SARING & V10 & 0,128598 \\
\hline HENDRA & V5 & 0,126486 \\
\hline EKO & V8 & 0,123718 \\
\hline RUSWANTO & V4 & 0,117489 \\
\hline ROHIDAH & V1 & 0,110953 \\
\hline SIDO & V9 & 0,104264 \\
\hline MARSONO & V6 & 0,099345 \\
\hline SUPRI & V3 & 0,084879 \\
\hline
\end{tabular}




\begin{tabular}{|l|c|c|}
\hline JUMARI & V2 & 0,055495 \\
\hline SUTAR YONO & V7 & 0,048773 \\
\hline & mean & 0,1000000000 \\
\hline
\end{tabular}

Berdasarkan tabel diatas mengunakan 10 sample maka di dapatkan nilai Mean sebagai berikut: 0,1000000000

Tabel.9 Pencarian Nilai S Kuadrat

\begin{tabular}{|c|c|c|}
\hline NO & \multicolumn{1}{|c|}{ KETERANGAN } & NILAI \\
\hline & Nilai S kuwadrat Wp & 0,08889 \\
\hline 1 & Nilai S kuwadrat Topsis & \\
2 & & 0,4781 \\
\hline
\end{tabular}

Berdasarkan tabel diatas mengunakan 10 sample maka di dapatkan nilai S kuwadrat sebagai berikut: $0,08889,0,4781$

Tabel.10 Pencarian Nilai Standar deviation

\begin{tabular}{|c|c|c|}
\hline NO & KETERANGAN & NILAI \\
\hline 1 & Standar deviation Wp & 0,29814 \\
\hline 2 & Standar deviation Topsis & 0,6914 \\
\hline
\end{tabular}

Berdasarkan tabel diatas mengunakan 10 sample maka di dapatkan nilai Standar deviation sebagai berikut: 0,29814, 0,6914

Tabel.11 Pencarian Nilai Standar Error

\begin{tabular}{|c|c|c|}
\hline \multirow{2}{*}{1} & KETERANGAN & NILAI \\
\hline \multirow{2}{*}{2} & Nilai Satandar error WP & 0,00889 \\
\cline { 3 - 3 } & & 0,09428 \\
\hline & Nilai Standar error Topsis & 0,0478 \\
\cline { 3 - 3 } & & 0,2186 \\
\hline
\end{tabular}

Berdasarkan tabel diatas mengunakan 10 sample maka di dapatkan nilai Standar Nilai Error sebagai berikut: 0,00889, 0,09428

Berdsatkan hasil perbandingan dari hasil table prediksi mengunakian metode WP dan Topsis di peroleh hasil sebagai berikut:

Tabel.12 Hasil WP

Column1
Mean

Standard Error

0,009043027

Median

0,107608288

Mode

\#N/A

Standard Deviation

0,028596561

Sample Variance

0,000817763

Kurtosis

$-0,276844079$

Skewness

$-0,97392137$

Range

0,079824853

Minimum

0,04877324

Maximum

0,128598093

Sum

Count

10

Berdasarkan tabel diatas mengunakan 10 sample maka di dapatkan nilai WP sebagai berikut:
Mean
$: 0,1$
Standard Deviation
: 0,028596561
Standar Error
: 0,009043027

Berdsatkan hasil perbandingan dari hasil table prediksi mengunakian metode A dan B di peroleh hasil sebagai berikut:

Tabel.13 Hasil Hasil Topsis

\begin{tabular}{lr}
\hline \multicolumn{2}{c}{ Columnl } \\
\hline Mean & 0,5 \\
Standard Error & 0,070137683 \\
Median & 0,605555353 \\
Mode & \#N/A \\
Standard Deviation & 0,221794827 \\
Sample Variance & 0,049192945 \\
Kurtosis & $-0,008880554$ \\
Skewness & $-1,047340517$ \\
Range & 0,643268234 \\
Minimum & 0,120224509 \\
Maximum & 0,763492743 \\
Sum & 5 \\
Count & 10 \\
\hline
\end{tabular}

Berdasarkan tabel diatas mengunakan 10 sample maka di dapatkan nilai Topsis sebagai berikut:

$\begin{array}{ll}\text { Mean } & : 0,5 \\ \text { Standard Deviation } & : 0,221794827 \\ \text { Standar Error } & : 0,070137683\end{array}$


Berdasarkan pengamatan menggunakan metode WP dan TOPSIS dengan melakukan pembobotan kami melihat bahwa kedua metode tersebut memiliki kesamaan dalam prosesnya, Tetapi dua metode ini menghasilkan nilai error berbeada maka disimpulkan hasil terkecillah yang terbaik (Topsis 0,070137683)

\section{KESIMPULAN DAN SARAN}

5.1 Kesimpulan

Berdasarkan pembahasan yang telah diuraikan, yaitu, tentang model pengmbiln keputusn penerima bantuan raskin dengan metode Weighted Product (WP) dan metode Topsis untuk data Penerima bantuan raskin di kecamatan Way Pengubuan Lampung Tengah, maka dapat disimpulkan beberapa hal sebagai berikut:

1. Sistem dapat memberikan rekomendasi calon penerima bantuan raskin untuk kecamatan way pengubuan sehingga dapat membantu pihak kecamatan dalam menentukan penerima bantuan raskin di kecamatan way pengubuan lampung tengah.

2. Berdasrkan hasil pengujian mengunakan metode Weighted Product (WP) dan metode Topsis dengan melakukan pembobotan kami melihat bahwa kedua metode tersebut memiliki kesamaan dalam prosesnya, Tetapi dua metode ini menghasilkan nilai error berbeada maka disimpulkan hasil terkecillah yang terbaik (Topsis 0,070137683)

\subsection{SARAN}

1. Perlunya penambahan data kriteria, misalnya system oprasi, platform, resolusi, maksimum layar dll

2. Dalam memecahkan masalah multikriteria metode Weighted Product (WP) dan Topsis bukan satu-satunya metode pengambilan keputusan yang dapat digunakan, alangkah banyaknya jika dicoba dibandigkan dengan mengunakan metode untuk mendukung keputusan yang lebih efektif

\section{DAFTAR PUSTAKA}

[1] Arifin, Danang. Sistem Pendukung Keputusan Penentuan Calon Penerima Bantuan Langsung Tunai (Blt) Menggunakan Metode Fcm Dan Topsis (Studi Kasus: Kantor Kecamatan Kampar Kiri Hilir). Diss. Universitas Islam Negeri Sultan Syarief Kasim Riau, 2013.
[2] Eniyati, Sri. "Perancangan Sistem Pendukung Pengambilan Keputusan untuk Penerimaan Beasiswa dengan Metode SAW (Simple Additive Weighting)." Dinamik 16.2 (2011).

[3] Handayani, Masitah. "Sistem Pendukung Keputusan Penentuan Penerimaan Raskin Di Menggunakan Metode Topsis." Jurnal Teknologi Informasi 1.1 (2017): 59-66.

[4] Kurniasih, Desi Leha. "Sistem pendukung keputusan pemilihan laptop dengan metode TOPSIS." Pelita Informatika: Informasi dan Informatika 3.2 (2017).

[5] Suryeni, Eni, Yoga Handoko Agustin, and Yuli Nurfitria. "Sistem Pendukung Keputusan Kelayakan Penerimaan Bantuan Beras Miskin Dengan Metode Weighted Product Di Kelurahan Karikil Kecamatan Mangkubumi Kota

Tasikmalaya." Proceedings

Konferensi Nasional Sistem dan Informatika (KNS\&I) (2015).

[5] Soleh, Ahmad. "Pertumbuhan Ekonomi dan Kemiskinan di Indonesia." Ekombis Review 2.2 (2014).

[7] Zai, Yosaaro, Mesran Mesran, and Efori Buulolo. "Sistem Pendukung Keputusan Untuk Menentukan Buah Rambutan Dengan Kualitas Terbaik Menggunakan Metode Weighted Product (Wp)." Media Informatika Budidarma

[8] Tukiran, Tukiran. "Penentuan Desa Miskin Analisis Potensial Desa 1990." Populasi 4.1.

[9] Efendi, Dwi Marisa, And Novita Novita. "Weight Product Dalam Implementasi Sistem Pendukung Keputusan Bantuan Bedah Rumah." Jurnal Informasi Dan Komputer 7.1 (2019): 35-42. 
